\title{
Disruption of Streptococcus mutans Biofilm by Rhamnolipid Biosurfactant Secreted from Pseudomonas aeruginosa ATCC10145
}

\author{
Mohd Aris Amira ${ }^{*}$, Tengku Zainal Elida ${ }^{1}$, Abdul Hazid Umi Marshida' ${ }^{1}$, M. F. Z. R. Yahya ${ }^{1}$ and \\ Affouad Saba ${ }^{2}$ \\ 'Center of Pure and Applied Biology, Department of Biomolecular Sciences, Faculty of Applied Sciences, Universiti \\ Teknologi MARA (UiTM), 40450 Shah Alam, Selangor, Malaysia; noramiraaris@gmail.com, tetzm@salam.uitm.edu.my, \\ umiabdhamid@yahoo.co.uk, fakharulzaman@salam.uitm.edu.my \\ ${ }^{2}$ Faculty of Dentistry, Universiti Teknologi MARA (UiTM), 47000 Sungai Buloh, Selangor, Malaysia; \\ drsabafouadhussain@gmail.com
}

\begin{abstract}
Objectives: The study was to examine the effect of rhamnolipid biosurfactant on Streptococcus mutans biofilm formation on orthodontic appliances. Methods/Statistical Analysis: Several properties of S. mutans cells such as formation of biofilm, detachment ability, the surface properties were changed after three different concentrations of biosurfactant treatment which were $10 \mathrm{mg} / \mathrm{ml}, 5 \mathrm{mg} / \mathrm{ml}$ and $2.5 \mathrm{mg} / \mathrm{ml}$. S. mutans biofilms were disrupted by rhamnolipids produced by Pseudomonas aeruginosa ATCC10145 at different concentrations and chlorhexidine digluconate $0.12 \%(\mathrm{v} / \mathrm{v})$ was used as positive control. Findings: The biosurfactant showed some antimicrobial activities against S. mutans with Minimum Inhibitory Concentration (MIC) varied from $10 \mathrm{mg} / \mathrm{ml}$ to $0.01 \mathrm{mg} / \mathrm{ml}$. MIC were observed at $1.25 \mathrm{mg} / \mathrm{ml}$ by microdilution 96-well plate method. The Minimum Bactericidal Concentration (MBC) was detected at a higher concentration of 10 $\mathrm{mg} / \mathrm{ml}$ by plating onto agar. The best treatment of dental biofilm formation was determined at $10 \mathrm{mg} / \mathrm{ml}$ showing the highest percentage of biofilm detachment which was $89.53 \%$. The biofilm development is commonly known as strongly dependent on hydrophobicity/hydrophilicity substrate properties using contact angle measurement. Higher percentage (89.53\%) of biofilm detachment determined at polystyrene surface compared to stainless steel surface with the aid of rhamnolipid. Rhamnolipid displayed a significant potential as disrupting agents against established biofilms produced by several bacterial and fungal species. Application/Improvements: P. aeruginosa were successfully extracted their crude biosurfactant to treat the growth of biofilm. Future studies can be performed on specific mechanisms on how biosurfactant inhibit and disrupt biofilm growth.
\end{abstract}

Keywords: Biofilm Formation, Biosurfactant, Pseudomonas Aeruginosa, Streptococcus mutans

\section{Introduction}

Biosurfactants, a structurally diverse group of surface active molecules utilized by microorganisms such as bacteria and fungi, had been studied and reported in recent years. In fact, they had several advantages over synthetic surfactants, such as non-toxic, biodegradable and ecological acceptability. Biosurfactants derived from their complex structures which include unique amphipathic properties, having a hydrophilic moiety and a hydrophobic portion ${ }^{1}$. S. mutans, harbouring the dental biofilm, is one of the etiological factors of dental caries ${ }^{2}$. The ability of this biofilm to adhere to the teeth surface is vital for the initiation and progression towards dental caries ${ }^{3-5}$. Several studies had reported the role of biosurfactant production in biofilm formation by different microor-

${ }^{*}$ Author for correspondence 
ganisms $\frac{6-9}{}$. The production of lipopeptide biosurfactants (known as putisolvins) secreted by Pseudomonas putida, involved in development of its biofilm ${ }^{10}$. In fact, biosurfactants have potential in altering cell surface properties of different microorganisms and also in interfering the initial adhesion to solid surfaces and formation of biofilm is widely investigated ${ }^{11-13}$.

This report demonstrated that S. mutans biofilms can be effectively disrupted by treatment with rhamnolipids secreted by P. aeruginosa ATCC10145 in vitro.

\section{Materials and Methods}

\subsection{Bacterial Strains and Growth Conditions}

Pseudomonas aeruginosa ATCC10145 and Streptococcus mutans ATCC25175 stock culture were maintained at $70 \%(\mathrm{v} / \mathrm{v})$ glycerol stock.

\subsection{Biosurfactants}

Rhamnolipid from P. aeruginosa was obtained as previously described ${ }^{14}$. Rhamnolipid biosurfactant was characterized based on previous study on production of biosurfactants by B. subtilis ATCC6633 and P. aeruginosa ATCC10145 under the influence of carbon and nitrogen sources and temperature (in publication).

\subsection{Microplate Biofilm Formation Assay}

Biofilm formation was tested in sterile 96-well microtiter flat-bottomed plastic tissue culture plates with a lid (Jet Bio-Fil) ${ }^{15}$. The wells were filled with $100 \mu$ of S. mutans suspension each. Negative control wells contained only culture suspension. Positive control wells contain culture suspension treated with $50 \mu \mathrm{L}$ of $0.12 \%(\mathrm{v} / \mathrm{v})$ chlorhexidine. For post treatment method, the preformed biofilms of S. mutans were treated with $50 \mu \mathrm{l}$ of different concentration of biosurfactant: $10 \mathrm{mg} / \mathrm{ml}, 5 \mathrm{mg} / \mathrm{ml}, 2.5 \mathrm{mg} / \mathrm{ml}$ and incubated for 24 hours at $37^{\circ} \mathrm{C}$ anaerobically. Each well was later washed three times with $200 \mu \mathrm{l}$ of sterile phosphate buffer saline. Biofilm cells were finally detached by pipetting action and suspended in the $100 \mu \mathrm{l}$ of PBS. The biofilm suspension was then used for Colony Forming Unit (CFU) counting.

\subsection{Viable Cell Counting}

The biofilm suspension was obtained from the microtiter plate biofilm formation assay. Dilution of biofilm fraction was made at a ratio of $1: 10^{4}$. A volume of $100 \mu \mathrm{L}$ of the biofilm suspension was spread on the sterile Tryptic Soy agar. The plates were then incubated anaerobically for 24 hours at $37^{\circ} \mathrm{C}$. The viable cells were counted to obtain $\mathrm{CFU} \mathrm{mL}^{-1} \underline{16}$.

\subsection{Minimum Inhibitory Concentration $(\mathrm{MBC})$}

A volume of $100 \mu \mathrm{l}$ of the rhamnolipid solution and Tryptic Soy broth (TSB) was dispensed in every well of Column 1, while Columns 2-12 contained $50 \mu$ of TSB broth only. Column 1 contained $100 \mu$ of the Tryptic Soy broth (as a control to monitor sterility). A pipette was used to transfer and mix biosurfactants solution from column 2-12, resulting in $50 \mu \mathrm{l}$ biosurfactants per well. The tested concentrations of the different biosurfactants achieved through two-fold serial dilutions from columns $2-12$ were as follows; $10-0.01 \mathrm{mg} / \mathrm{ml}$. A volume of 50 $\mu \mathrm{l}$ of the adjusted $\mathrm{OD}_{600} \mathrm{~nm} \mathrm{~S}$. mutans suspension was added to all well containing biosurfactant, according to MacFarland 0.5. After incubation for 24 hours at $37^{\circ} \mathrm{C}$, resazurin which act as indicator was added to all wells ( 30 $\mu \mathrm{l}$ per well), and then further incubated for 1 hour, 100 $\mathrm{rpm}$ at $37^{\circ} \mathrm{C}$ for the observation of colour changes ${ }^{17}$.

\subsection{Minimum Biocidal Concentration (MBC)}

The bacterial suspension of three test concentrations greater than or equal MIC were streaked on Tryptic Soy Agar (TSA) plates using sterile wire loop and incubated overnight at $37^{\circ} \mathrm{C}$. The lowest concentration of the biosurfactant extracts which showed no growth of organism on plates after 24 hours of incubation was considered as $\mathrm{MBC}^{\underline{16}}$.

\subsection{Dental Material Preparation}

Thirty permanent bovine permanent incisors (Faculty of Dentristy, UiTM Sungai Buloh, Selangor, Malaysia) were collected for this study. All teeth were thoroughly examined to be free of caries and no obvious defects. The teeth were prepared initially by cutting the root and washed using distilled water and stored in a dry container.

\subsection{Biofilm Development on Orthodontic Bracket}

The lower incisor brackets (uniform size) of $3 \mathrm{M}$ Unitek (USA) were chosen for the biofilm study. S. mutans bio- 
film developed on bracket as described by with slight modification. Briefly, the sterilized brackets which were transferred into 12-well tissue culture plate and incubated with $300 \mu \mathrm{L}$ culture suspension at a concentration of $10^{5}-$ $10^{6} \mathrm{CFU} / \mathrm{mL}(0.5 \mathrm{McF}$ arland standard at $600 \mathrm{~nm})$ and the plates were incubated anaerobically at $37^{\circ} \mathrm{C}$ as a static culture for 24 hours ${ }^{18}$.

\subsection{Adherence of Biosurfactants (Biosurfactant Precoating)}

The effect of biosurfactant on biofilm attachment was tested by using 24 -wells tissue culture plate. Initially, the biosurfactant is dissolved in the medium and later utilized at one selected concentration. The tested groups were labelled as sample (biosurfactant), positive control and negative control. The bovine teeth bonded with stainless steel orthodontic bracket were placed into each well using a tweezer. A volume of $300 \mu \mathrm{l}$ culture suspension was added to each well and later incubated. After 24 hours anaerobically incubated, the preformed biofilm was treated with $150 \mu \mathrm{L}$ biosurfactant. For positive control and negative control, $150 \mu \mathrm{L}$ of $0.12 \%(\mathrm{v} / \mathrm{v})$ chlorohexidine and distilled water respectively was added to their wells that were not precoated with any biosurfactant and incubated together with the inoculum for 24 hours. Each bovine teeth bonded with bracket was later transferred into sterile test tube. Planktonic cells were removed by gently washing three times with $200 \mu \mathrm{L}$ of sterile PBS. Biofilm cells were detached by vortexing them for several minutes in $300 \mu \mathrm{L}$ of PBS. The biofilm suspension was then used for Colony Forming Unit (CFU) counting. For obtaining the best results, the experiment was performed in triplicates ${ }^{19}$.

\subsection{Qualitative Observation of the Biofilm}

Scanning Electron Microscopy (SEM) was used to observe the biofilm already formed on the surfaces. Briefly, the 12-well tissue culture plate after 24 hours of biofilm treatment fixed with $100 \%(\mathrm{v} / \mathrm{v})$ methanol for 30 minutes, dehydrated for 10 minutes at concentration of 50, 70, 80, 90, 95 and 100\% (v/v) graded ethanol and finally treated under UV light. Specimens were fixed on aluminium stubs using a conductive carbon tape, covered with a 10-nm gold layer (Coating Unit 5100; Polaron) and observed with a scanning electron microscope (Jeol 840 A) at various magnifications, using secondary electrons at $15 \mathrm{kV}$.

\section{Results and Discussion}

\subsection{Disruption of Preformed Biofilms of S. mutans}

S. mutans biofilms were treated with biosurfactants at three different concentrations of 10,5 and $2.5 \mathrm{mg} / \mathrm{ml}$. The detachment percentage of the biofilm revealed that S. mutans showed affinity to the polystyrene microtitre plate's surface. The attached bacterial cells were collected from the wells of microtiter plates (Figure 1) and used for colony forming unit. Based on Figure 2 it can be proven that increasing biosurfactant concentration leading to higher disruption of biofilm under observation of naked eyes. The growth of S. mutans biofilm was compared before and after rhamnolipid treatment. Based on Figure 3 , biofilms of S. mutans in microtiter plate wells were efficiently disrupted by rhamnolipid when the percentage of biofilm disrupted increased with increasing biosurfactant concentration. The treatment with rhamnolipid at $2.5 \mathrm{mg} / \mathrm{ml}$ concentration removed about $70.07 \%$ of the biofilm after 24 hours contact and the increase in concentration of rhamnolipid applied from $5 \mathrm{mg} / \mathrm{ml}$ and $10 \mathrm{mg} /$ $\mathrm{ml}$ increased the biofilm disruption at $84.68 \%$ and $89.53 \%$ respectively after 24 hours incubation.

The results may be associated with the increase in the number of biosurfactants adsorbed to the surface. $\mathrm{In}^{20}$ studied that rhamnolipids at high concentration was required to coat the silicone rubber in order to reduce the attachment of the Staphylococcus aureus, Staphylococcus epidermidis, Streptococcus salivarius and Candida tropicalis. They reported that the reason could be due to the washing out of rhamnolipids layer adsorbed, since rhamnolipids are bonded in the surface by weak forces. The disruption of biofilms was affected by biosurfactant concentration which was also investigated by ${ }^{21}$ who reported that $100 \mathrm{mM}$ rhamnolipids has the ability to disrupt $93 \%$ of the biofilm Bacillus pumilus while at concentrations below $0.4 \mathrm{mM}$ biofilm removal was not observed. Van der Waals interactions involved during initial attachment of bacteria to the surface, which also involves electrostatic and hydrophobic interactions ${ }^{22}$. The biosurfactant layer in the surface might modify these interactions and then interrupt the ability of the bacteria to adhere ${ }^{20}$. Seeding dispersion is an active mechanism, where cells detachment occurred during final stages of biofilm formation and actively mediated by rhamnolipids $\frac{23-25}{}$ In $^{24}$ reported that rhamnolipid-mediated detachment mechanism 
involved the development of cavities within the centre of biofilm structures. The surfactants showing effectiveness in removing biofilms, as they penetrated into the interface between the solid substrate and the biofilm so they could adsorb at the interface and then reduced the interfacial tension. Therefore, the attractive interactions between the solid surface and the bacterial surfaces may be reduced, which would be easier for the removal of the film ${ }^{26}$.

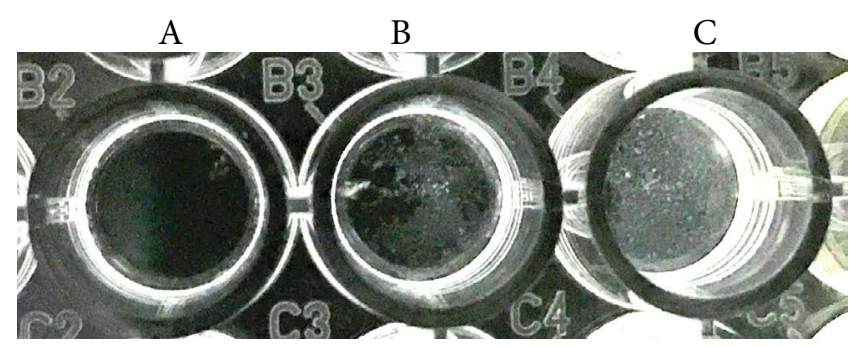

Figure 1. Attached cells (biofilm) after 24 hours treatment with rhamnolipid at three different concentrations a) $10 \mathrm{mg} /$ $\mathrm{ml}$, b) $5 \mathrm{mg} / \mathrm{ml}$ and c) $2.5 \mathrm{mg} / \mathrm{ml}$ in 96 well microtiter plate. Arrow indication of the attached S. mutans biofilm after rhamnolipid treatment.

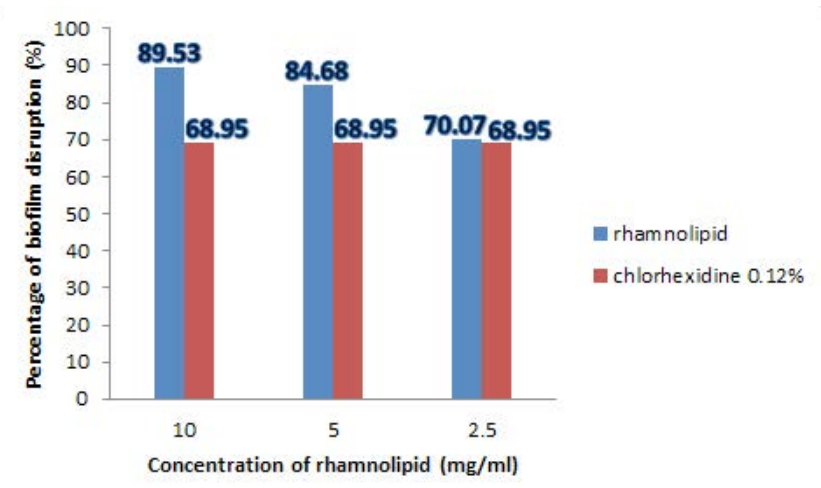

Figure 2. Inhibition of attachment of S. mutans biofilm to polystyrene conditioned with biosurfactants at three different concentrations: $10 \mathrm{mg} / \mathrm{ml}, 5 \mathrm{mg} / \mathrm{ml}$ and $2.5 \mathrm{mg} / \mathrm{ml}$.

\subsection{Minimum Inhibitory Concentration (MIC) and Minimum Bactericidal Concentration (MBC)}

The Kirby-Bauer antibacterial activity of crude biosurfactant was analysed by a microdilution method in 96-well microtiter plate. Based on results in Table 1, the MIC of rhamnolipid against $\mathrm{S}$. mutans biofilm was at concentration $1.25 \mathrm{mg} / \mathrm{ml}$. Changes in colour of broth culture into blue or purple after treatment with resazurin dye indicated positive result. Whilst changes in the colour of broth into pink after treatement with resazurin dye indicated nega- tive result. The values for MIC obtained in this study were lower than the values for MBC where the value of $\mathrm{MBC}$ was $10 \mathrm{mg} / \mathrm{ml}$ as shown in Table 2. The MBC was determined as the lowest concentration of antibacterial agent that reduced the viability of the initial bacterial inoculum by a pre-determined reduction such as $\geq 99.9 \%$. These results suggested that the rhamnolipid was categorized as bacteriostatic at lower concentration and bactericidal at higher concentration. The MIC values for the rhamnolipid against the $\mathrm{S}$. mutans were found to be lower than antibiotic amoxicillin $(3.75 \mathrm{mg} / \mathrm{ml})$ which acted as positive control. $\mathrm{In}^{27}$ revealed that for an antimicrobial substance, if the ratio of $\mathrm{MIC} / \mathrm{MBC} \leq 4$, the antibacterial substance can be considered as bactericidal. Thus, based on the ratio of MIC/MBC of this study proved that rhamnolipid can be considered as bactericidal.

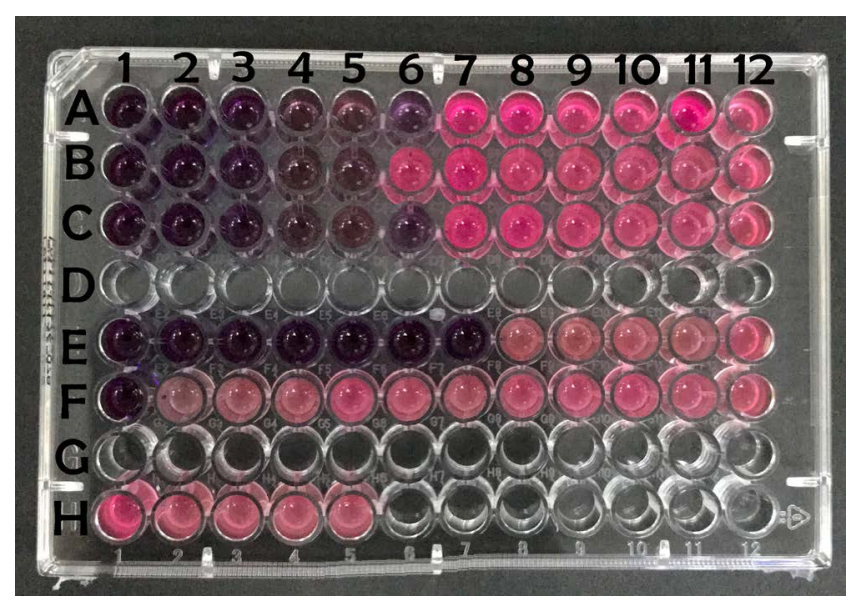

Figure 3. Disruption of S. mutans biofilm by rhamnolipid using 96-well microtiter plate. After 24 hours of incubation, resazurin dye was added. Column 1: The broth indication no contamination. Colum 2 to 12 : The highest concentration, $10 \mathrm{mg} / \mathrm{ml}$ of rhamnolipid was incorporated into column 2 and the lowest rhamnolipid was achieved through twofold serial dilution, $0.01 \mathrm{mg} / \mathrm{ml}$ at column 12. Row $\mathrm{H}$ : The positive control which showed change in colour of resazurin (culture with treatment) to red-colourless (reduced form).

\subsection{Biofilm Detachment from Stainless Steel Bracket}

\subsection{Magnification of Biofilm before and after Treatment with Rhamnolipid using Scanning Electron Microscopy (SEM)}

Figure 4 showed the SEM images of gold-coated biofilms under original magnification 7000x. Treatment 
Table 1. Determination of Minimum Inhibitory Concentration (MIC) of rhamnolipid (triplicate data) against S. mutan biofilm

\begin{tabular}{|l|l|l|l|l|l|l|l|l|l|l|l|l|}
\hline \multirow{2}{*}{ Bacteria } & \multicolumn{7}{|c|}{ Biosurfactant concentration in each well $(\mathrm{mg} / \mathrm{ml})$} & $\begin{array}{l}\text { Negative } \\
\text { control }\end{array}$ \\
\cline { 2 - 13 } & 10 & 5 & 2.5 & 1.25 & 0.625 & 0.313 & 0.156 & 0.078 & 0.039 & 0.02 & 0.01 & + \\
\hline S. mutans & - & - & - & - & + & + & + & + & + & + & + & + \\
\hline
\end{tabular}

+-- Presence of growth

- --- Absence of growth

Negative control: Broth only

of S. mutans biofilms with rhamnolipids resulted in the removal of the biofilm.

Further studies on the action of glycolipid alone or synergistically combined with other compounds such as antibiotics can give great importance in the study of biosurfactant in dental applications.

Table 2. Summarization of Minimum Inhibitory Concentration (MIC) and Minimal Bactericidal Concentration (MBC) for rhamnolipid against $S$. mutans biofilm

\begin{tabular}{|l|l|l|}
\hline Bacterial strain & Antimicrobial agent & \\
\hline & Rhamnolipid & \\
\hline & MIC $(\mathbf{m g} / \mathbf{m l})$ & $\begin{array}{l}\text { MBC }(\mathbf{m g} / \\
\mathbf{m l})\end{array}$ \\
\hline S. mutans biofilm & 1.25 & 10 \\
\hline
\end{tabular}

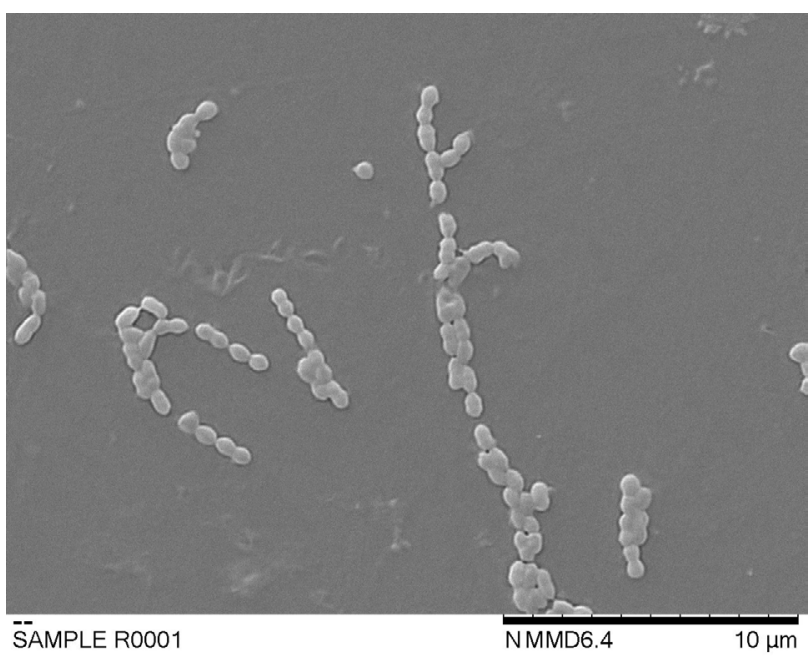

\subsection{Contact Angle Measurements}

The water Contact Angle (CA) formed on both solid surfaces before and after treatment with rhamnolipid was shown in Table 3. Water contact angles can be used as a qualitative indication of the surface material hydrophobicity, with higher values indicating a more hydrophobic surface. According to ${ }^{28}$ when water contact angle of a surface is more than $65^{\circ}$, it was considered as hydrophobic, therefore, polystyrene is hydrophobic and stainless steel is a hydrophilic surface. Before treatment, the materials presented a contact angle of $86^{\circ}$ for polystyrene and $42^{\circ}$ for stainless steel bracket, demonstrating the hydrophobic nature of polystyrene and the hydrophilic nature of stainless steel bracket. Both stainless steel and polystyrene surface after rhamnolipid treatment, showed reduction in CA (Table 4) indicating biosurfactant conditioning causes a change in the contact angle. Rhamnolipid treatment increases CA rendering the surface to more hydrophobic characteristics on stainless steel. The CA measurement showed that the conditioning treatment with rhamnolipid

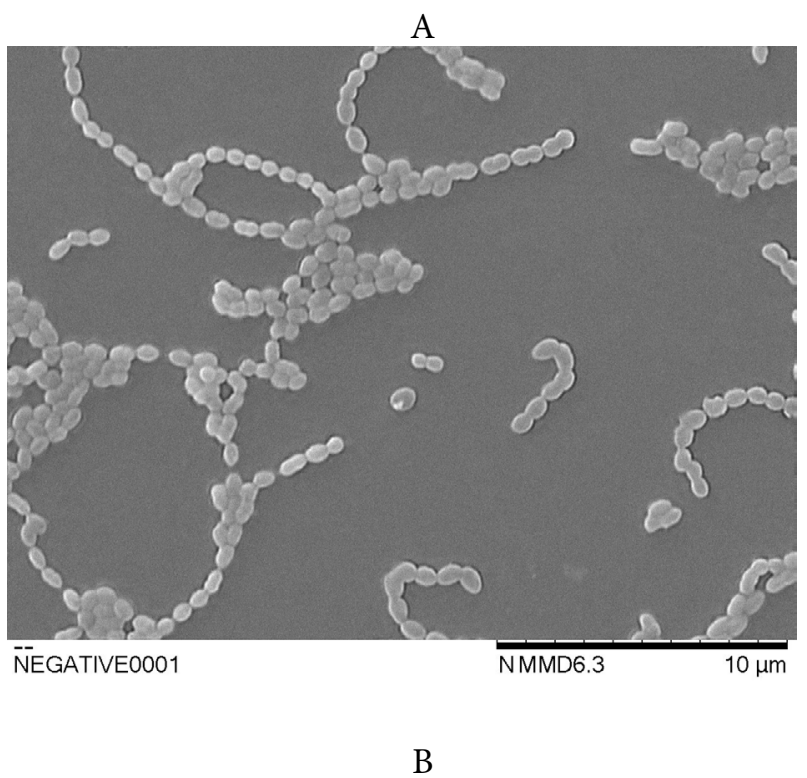

Figure 4. SEM images of $24 \mathrm{~h}$ biofilms of S. mutans formed on polystyrene surface (a) without biosurfactant addition and (b) after 24 hour treatment with rhamnolipid at concentration of $10 \mathrm{mg} / \mathrm{ml}$ solution under $7000 \mathrm{x}$ magnification. Bar scale $10 \mu \mathrm{m}$. ${ }^{\star}$ Arrow indicated the burst part of biofilm cells caused by rhamnolipid treatment. 
reduces the hydrophobicity of the polystyrene surface down to $69^{\circ}$. The biosurfactant conditioning causes a change in the contact angle. These results showed the importance of the hydrophobic effect of the biomaterial surface in initial adhesion. Rhamnolipid treatment gives higher hydropobic effect to the biomaterial surface that makes the biofilm easily dispersed.

Table 3. Inhibition of attachment of S. mutans biofilm to stainless steel braces conditioned with $10 \mathrm{mg} / \mathrm{ml}$ rhamnolipid and $0.12 \%(\mathrm{v} / \mathrm{v})$ chlorhexidine

\begin{tabular}{|l|l|}
\hline Conditioning treatment & $\begin{array}{l}\text { Percentage biofilm } \\
\text { detachment (\%) }\end{array}$ \\
\hline Rhamnolipid at $10 \mathrm{mg} / \mathrm{ml}$ & 9.88 \\
\hline $\begin{array}{l}\text { Positive control (Chlorhexidine } \\
\text { at } 0.12 \%)\end{array}$ & \\
\hline
\end{tabular}

Table 4. Contact angle readings of orthodontic bracket and polystyrene surfaces before and after conditioning with rhamnolipid

\begin{tabular}{|l|l|l|}
\hline \multirow{2}{*}{$\begin{array}{l}\text { Conditioning } \\
\text { treatment }\end{array}$} & \multicolumn{2}{|l|}{ Contact angle $(\mathbf{)})$} \\
\cline { 2 - 3 } & Polystyrene & $\begin{array}{l}\text { Stainless steel } \\
\text { bracket }\end{array}$ \\
\hline Broth only (control) & $86.50, \pm 2.18$ & $42.20, \pm 5.2$ \\
\hline Rhamnolipid & $69.40, \pm 4.0$ & $54.00, \pm 0.9$ \\
\hline
\end{tabular}

\section{Conclusions}

This study demonstrated that the rhamnolipid was an effective antibiofilm agent that was able to disrupt the attachment ability of pathogen S. mutans biofilm and the percentage between commercial antibiofilm (chlorhexidine at $0.12 \%(\mathrm{v} / \mathrm{v}))$ was not too much difference. The disruption effect shows to be dependent on biosurfactant concentration. However, the best result was obtained by the pre-conditioning with $10 \mathrm{mg} / \mathrm{ml}$ rhamnolipid biosurfactant on 96-well microtiter plate assay when the percentage of biofilm disruption showed $89.53 \%$. However, there is a need for optimization in production of biosurfactants in large quantities to fullfil the market requirement. It was suggested that $10 \mathrm{mg} / \mathrm{ml}$ of biosurfactant concentration that need to be applied to the orthodontic appliances.

\section{Acknowledgment}

The authors are thankful to the management of Faculty of Applied Sciences and Faculty of Dentristry for provid- ing the facilities and grateful support in the mission of completing this work. This research was supported by Ministry of Higher Education awarded to UiTM under a grant numbered 600-IRMI/FRGS 5/3 (30/2014).

\section{References}

1. Vater J, Kablits B, Wild C, Franke P, Mehta N, Cameotra SS. Matrix-assisted laser desorption ionization-time of flight mass spectrometry of lipopeptide biosurfactants in whole cells and culture filtrates of bacillus subtilis c-1 isolated from petroleum sludge. Applied and Environmental Microbiology. 2002; 68(12):6210-9. PMid: 12450846 PMCid: PMC134408. https://doi.org/10.1128/ AEM.68.12.6210-6219.2002

2. Marsh PD. Are dental diseases examples of ecological catastrophes? Microbiology. 2003; 149(2):279-94. PMid: 12624191. https://doi.org/10.1099/mic.0.26082-0

3. Caglar E, Kargul B, Tanbogaet I. Bacteriotherapy and probiotics role on oral health. Oral Diseases. 2005; 11(3):131-7. PMid: 15888102. https://doi.org/10.1111/ j.1601-0825.2005.01109.x

4. Tam A, Shemesh M, Wormser U, Sintov A, Steinberg D. Effect of different iodine formulations on the expression and activity of Streptococcus mutans glucosyltransferase and fructosyltransferase in biofilm and planktonic environments. Journal of Antimicrobial Chemotherapy. 2006; 57(5):865-71. PMid: 16549514. https://doi.org/10.1093/ jac/dkl085

5. Barbieri VAD, Vicente VA, Fraiz FC, Lavoranti OJ, Svidzinski TIE, Pinheiro RL. Analysis of the in vitro adherence of Streptococcus mutans and Candida albicans. Brazilian Journal of Microbiology. 2007; 38(4):624-31. https://doi.org/10.1590/S1517-83822007000400009

6. Mireles JR, Toguchi A, Harshey RM. Salmonella enterica serovar typhimurium swarming mutants with altered biofilm-forming abilities: Surfactin inhibits biofilm formation. Journal of Bacteriology. 2001; 183(20):5848-54. PMid: 11566982 PMCid: PMC99661. https://doi.org/10.1128/ JB.183.20.5848-5854.2001

7. Walencka E, Rozalska S, Sadowska B, Rozalska B. The influence of Lactobacillus acidophilus-derived surfactants on staphylococcal adhesion and biofilm formation. Folia Microbiologica. 2008; 53(1):61-6. PMid: 18481220. https:// doi.org/10.1007/s12223-008-0009-y

8. Rivardo F, Turner RJ, Allegrone G, Ceri H, Martinotti MG. Anti-adhesion activity of two biosurfactants produced by Bacillus spp. prevents biofilm formation of human bacterial pathogens. Applied Microbiology and Biotechnology. 2009; 83(3):541-53. PMid: 19343338. https://doi.org/10.1007/s00253-009-1987-7 
9. Kanmani P, Satish Kumar R, Yuvaraj N, Paari KA, Pattukumar V, Arul V. Production and purification of a novel exopolysaccharide from lactic acid bacterium Streptococcus phocae PI80 and its functional characteristics activity in vitro. Bioresource Technology. 2011; 102(7):4827-33. PMid: 21300540. https://doi.org/10.1016/j. biortech.2010.12.118

10. Kuiper I, Lagendijk EL, Pickford R, Derrick JP, Lamers GEM, Thomas-Oates JE, Lugtenberg BJJ, Bloemberg GV. Characterization of two Pseudomonas putida lipopeptide biosurfactants, putisolvin I and II, which inhibit biofilm formation and break down existing biofilms. Molecular Microbiology. 2004; 51(1):97-113. https://doi.org/10.1046/ j.1365-2958.2003.03751.x

11. Ron EZ, Rosenberg E. Natural roles of biosurfactants. Environmental Microbiology. 2001; 3(4):229-36. PMid: 11359508. https://doi.org/10.1046/ j.1462-2920.2001.00190.x

12. Flemming HC, Wingender J. The biofilm matrix. Nature Reviews Microbiology. 2010; 8(9):623-33. PMid: 20676145. https://doi.org/10.1038/nrmicro2415

13. Rendueles O, Ghigo JM. Multi-species biofilms: How to avoid unfriendly neighbors. FEMS Microbiology Reviews. 2012; 36(5):972-89. PMid: 22273363. https://doi. org/10.1111/j.1574-6976.2012.00328.x

14. Thaniyavarn J, Chongchin A, Wanitsuksombut N, Thaniyavarn S, Pinphanichakarn P, Leepipatpiboon N, Morikawa M, Kanaya S. Biosurfactant production by Pseudomonas aeruginosa A41 using palm oil as carbon source. The Journal of General and Applied Microbiology. 2006; 52(4):215-22. PMid: 17116970. https://doi. org/10.2323/jgam.52.215

15. Stepanovic S, Vukovic D, Hola V, Di Bonaventura G, Djukic S, Cirkovic I, Ruzicka F. Quantification of biofilm in microtiter plates: Overview of testing conditions and practical recommendations for assessment of biofilm production by staphylococci. Acta Pathologica, Microbiologica, Et Immunologica Scandinavica (APMIS). 2007; 115(8):891-9. PMid: 17696944. https://doi.org/10.1111/j.1600-0463.2007. apm_630.x

16. Yahya MFZR, Ibrahim MSA, Zawawi WMAWM, Hamid UMA. Biofilm killing effects of chromolaena odorata extracts against Pseudomonas aeruginosa. Research Journal of Phytochemistry. 2014; 8(3):64-73. https://doi. org/10.3923/rjphyto.2014.64.73

17. Elshikh M, Ahmed S, Funston S, Dunlop P, McGaw M, Marchant R, Banat IM. Resazurin-based 96-well plate microdilution method for the determination of Minimum Inhibitory Concentration of biosurfactants. Biotechnology Letters. 2016; 38(6):1015-9. PMid: 26969604 PMCid: PMC4853446. https://doi.org/10.1007/s10529-016-2079-2
18. Chen Y, Wong RWK, Seneviratne CJ, Hagg U, McGrath C, Samaranayake LP, Kao R. The antimicrobial efficacy of Fructus mume extract on orthodontic bracket: A monospecies-biofilm model study in vitro. Archives of Oral Biology. 2011; 56(1):16-21. PMid: 20864088. https://doi.org/10.1016/j.archoralbio.2010.08.006

19. Cochis A, Fracchia L, Martinotti MG, Rimondini L. Biosurfactants prevent in vitro Candida albicans biofilm formation on resins and silicon materials for prosthetic devices. Oral Surgery, Oral Medicine, Oral Pathology and Oral Radiology. 2012; 113(6):755-61. PMid: 22668702. https://doi.org/10.1016/j.oooo.2011.11.004

20. Rodrigues LR, Banat IM, van der Mei HC, Teixeira JA, Oliveira R. Interference in adhesion of bacteria and yeasts isolated from explanted voice prostheses to silicone rubber by rhamnolipids biosurfactants. Journal of Applied Microbiology. 2006; 100(3):470-80. PMid: 16478486. https://doi.org/10.1111/j.1365-2672.2005.02826.x

21. Dusane DH, Nancharaiah V, Zinjarde SS, Venugopalan VP. Rhamnolipid mediated disruption of marine Bacillus pumilus biofilms. Colloids and Surfaces B: Biointerfaces. 2010; 81(1):242-8. PMid: 20688490. https://doi.org/10.1016/j. colsurfb.2010.07.013

22. Nostro A, Scaffaro R, Ginestra G, D’Arrigo M, Botta L, Marino A, Bisignano G. Control of biofilm formation by poly-ethylene-co-vinyl acetate films incorporating nisin. Applied Microbiology and Biotechnology. 2010; 87(2):729-37. PMid: 20414650. https://doi.org/10.1007/ s00253-010-2598-Z

23. Schooling SR, Charaf UK, Allison DG, Gilbert P. A role for rhamnolipid in biofilm dispersion. Biofilms. 2004; 1(2):919. https://doi.org/10.1017/S147905050400119X

24. Boles BR, Thoendel M, Singh PK. Rhamnolipids mediate detachment of Pseudomonas aeruginosa from biofilms. Molecular Microbiology. 2005; 57(5):1210-23. PMid: 16101996. https://doi.org/10.1111/ j.1365-2958.2005.04743.x

25. Wang J, Yu B, Tian D, Ni M. Rhamnolipid but not motility is associated with the initiation of biofilm seeding dispersal of Pseudomonas aeruginosa strain PA17. Journal of Biosciences. 2013; 38(1):149-56. PMid: 23385822. https:// doi.org/10.1007/s12038-012-9297-0

26. McLandsborough L, Rodriguez A, Pérez-Conesa D, Weiss J. Biofilms: at the interface between biophysics and microbiology. Foods Biophysics. 2006; 1(2):94-114. https://doi. org/10.1007/s11483-005-9004-x

27. Oussou KR, Coffi K, Nathalie G, Seriyolou Gerard K, Mireille D, Yao TN, Gilles F, Jean-Claude CH. Activités antibacteriennes des huiles essentielles de trois plantes aromatiques de Côte d'Ivoire. Comptes Rendues de Chimie. 2004; 7(10-11):1081-6. https://doi.org/10.1016/j. crci.2003.12.034 
28. Valcarce MB, Busalmen JP, Sanchez SR. The influence of the surface condition on the adhesion of Pseudomonas fluorescens (ATCC 17552) to copper and aluminium brass. International Biodeterioration and Biodegradation. 2002; 50(1):61-6. https://doi.org/10.1016/S09648305(02)00068-9 